\title{
Ego Conceptual Space in Emily Dickinson's Poetry
}

\author{
N. Yemets \\ Kyiv National Linguistic University, Kyiv, Ukraine \\ Corresponding author. E-mail: nataliiayemets5@gmail.com
}

Paper received 06.09.20; Accepted for publication 19.09.20.

\section{https://doi.org/10.31174/SEND-Ph2020-235VIII70-16}

\begin{abstract}
The article deals with the analysis of EGO conceptual space (CS) in Emily Dickinson's poetry. The work is founded on the theoretical basis of cognitive studies, conceptology and liguopoetics. Quantitative-qualitative analysis of ego-marked propositions in the poetic texts enables the identification of leading theme lines of E. Dickinson's poetic legacy. Within the theme lines, the dominants of EGO CS are reconstructed. On the ground of thematic domains structure, the EGO CS with specific concept distribution is modeled.

Keywords: conceptology, poetics, artistic concept, conceptual space, EGO conceptual space.
\end{abstract}

Introduction. Egocentricity as reality perception where personal "I" holds the central role is the main determinant of personality evolution in the whole spectrum of physical, spiritual and social development. The changes of the life environment, cooperation forms, and level of self-reflection influence the personality concept formation and offer the approaches to its identification.

Personality concept in the philosophical aspect is represented by EGO category that evolves in frames of the dominant scientific paradigm: on the way from the natural personality of Ancient World to the rational human of the modern society, the changes of the personality's position in the Universe are traced. Psychological sciences offer their approach to personality concept identification - from Freud's theory [4], through the transformational theories, humanistic and social psychology to "narrative" approach, the changes in the psychological egocentricity category are observed.

Review. Linguistic personality concept has become the central research issue in numerous investigations. Cognitive linguistics [3], in its turn, operating with the category of concept on the mental level, touches the depths of consciousness and mental representation of general philosophic categories [5].

Egocentricity conceptualization - is a mental representation of self-reflective aspects of world perception. EGO concept, in its turn, is a coding unit of conceptual picture of the world that holds the information of personal "I" where historical and cultural aspects serve as main determinants in egocentricity actualization.

In frames of cognitive investigations, artistic concepts emerge as the determining instrument in poetic picture of the world structuring. Artistic concepts, defined as constituents of the author's conceptual picture of the world, form the mental construct of world's representation.

Egocentricity in poetic texts [7] is represented by EGO concept - the basic unit of author's self-reflective part of conceptual picture of the world. The peculiarities of EGO concept actualization are determined by unique poetic texts structure, where the conceptual space is formed only with reader's cooperation [8].

Aim. The article is aimed at defining EGO concept peculiarities actualization in Emily Dickinson's poetic texts. The methodological background, resting on the general principles of linguopoetics, is represented by the complex approach to EGO artistic concept analysis as to a special macrotextual construct. Based on the artistic concept modeling procedure of V.H. Nikonova [9], taking into account the peculiar EGO concept status, the following method of investigation is developed: 1) defining ego-marked metaphorical contexts of propositions with egocentric words [6], 2) iden- tification of key theme lines and reconstruction of thematic dominants in conceptual metaphor terms in EGO conceptual space, 3) E. Dickinson's EGO CS modeling, 4) analysis of nuclear theme lines of ego-marked fragments and concept distribution in EGO CS structure.

Results discussion. Emily Dickinson's EGO CS investigation should be preceded by a glimpse into American Romanticism. This period is characterized by attention to the spiritual values, dialogue between real and imaginary worlds, appreciation of traditions. Dickinson, still being a part of the American Romantic tradition, is known for her unique independence from the literary standards: in search of answers of her personal sufferings reasons, she speculates on the topics of religion and nature balance. Her texts, sharp and ironic, touch the depths of every reader's soul [1].

Analysis of ego-marked contexts of Dickinson's works explicates five dominant theme lines: death, love, life, selfreflection and divine. Within the lines, fourteen thematic dominants - conceptual metaphors - are reconstructed.

The most numerous in its text representation is the death line that embraces $27,6 \%$ of the general textual verbalization in ego-marked contexts. In frames of this line, the following dominants are reconstructed: DEATH IS FEAR, DEATH IS ETERNITY, DEATH IS A ROAD, and DEATH IS BLISS.

The nuclei concepts of DEATH IS FEAR dominant are DEATH, FEAR and GOD. Death in Dickinson's works is, first of all, the fear of chaos and cold darkness. EGO CS of this dominant accumulates the artistic concepts of "cold poetry" to define the death as the situation of cold: "My wheel is in the dark-/I cannot see a spoke" [2, p. 260].

Life infinity can be reached by the soul transformation into immortality dimension which is the kingdom of eternity. The artistic concepts of DEATH IS ETERNITY space form EGO CS in the dimension of eternal life of soul in the new world that becomes the enlightenment of true life values: "I made my soul familiar / With her extremity. / That at the last it should not be / A novel agony. I But she and Death, acquainted, / Meet tranquilly as friends, / Salute and pass without a hint-/And there the matter ends" [2, p. 200].

The lines above explicate EGO CS of the thematic dominant DEATH IS A ROAD where the transition to a new state emerges as the act of birth. In this context, the artistic concept WATER becomes a symbol of purification and rebirth of soul and body: "So set its sun in thee, / Thy shore?" [2, p. 319]. Like a child's baptizing that through water cleanliness unites with God, so does physical death transform through water to the life in New World: "So keep your secret, Father! / I would not if I could, / Know what the sapphire fellows do, / In your new-fashioned world!" [2, p. 91].

Emily Dickinson was the first to speculate on death with 
irony and skepticism. Her predecessors and contemporaries, as a rule, referred to death in tragic colors. Dickinson, in her turn, ruins the stereotypes of divine by allowing herself to "argue" with death: "God preaches, - a noted clergyman, - / And the sermon is never long; / So instead of getting to heaven at last, / I'm going all along" [2, p. 114].

The conceptual dominant DEATH IS BLISS reflects the attitude to death as to the happiness of new life: "That bells should joyful ring to tell / A soul had gone to heaven, I Would seem to me the proper way / A good news should be given" [2, p. 241].

The next theme line identified in ego-marked contexts in Dickinson's poetry is the line of love with the following thematic dominants: LOVE IS PAIN and LOVE IS A NATURAL PHENOMENON. Such conceptual dominants in Dickinson's works are not accidental: though the love object of hers still remains unknown, the fact of her loneliness cannot be contradicted. This state caused the bright feeling of love reflection in dark colors of pain and suffering. Nature, in its turn, as an ideal creation of God, became the example of ideal love for Emily.

The nucleus artistic concept WATER, representing strength and purity, proves the dominant archetype of WATER that underlies the poetic texts of Romanticism: "He touched me, so I live to know / ... / It was a boundless place to me, / And silenced, as the awful sea / Puts minor streams to rest" [2, p. 172].Other artistic concepts, such as LIFE, LIGHT, WARMTH and EDEN function in the thematic space of love together with concepts FLOWER, BIRD and INSECT, thus proving the validity of the dominant: "Summer for thee grand I may be / When summer days are flown! I ... / For thee I bloom, I'll skip the tomb / And sow my blossoms o'er! / Pray gather me, Anemone, / Thy flower forevermore" [2, p. 166].

The theme line of life is the next in contextual representation in ego-marked contexts of Dickinson's poetry. Comparing the source domains of theme dominants, it is essential to state the similarity of three domains: LIFE IS A ROAD and DEATH IS A ROAD, LIFE IS FEAR and DEATH IS FEAR and LIFE IS BLISS and DEATH IS BLISS. The identical source domain in conceptualizing the antonymous notions reflects the life cycle continuity.

Conceptual dominant LIFE IS A JOURNEY is a conventional conceptual metaphor that parallels life to a road. The road of life in Dickinson's poetry is mostly a water way through ocean, sea or river (concepts OCEAN, SEA and RIVER): "It was such a gallant, gallant sea / That beckoned it away" [2, p. 19].

Another conventional conceptual metaphor of the thematic dominant is LIFE IS A CONTAINER. Artistic concepts distribution within this dominant demonstrates author's conceptualization of life in terms of a locked space: life on earth is represented as a locked container, where breaking through it opens new life horizons. Artistic concept DOOR in EGO CS represents the way to enlightenment ("open doors"): "A door just opened on a street / I, lost, was passing by - / ... / Lost doubly, but by contrast most, / Enlightenment misery" [2, p. 66].

The artistic concepts of thematic dominant LIFE IS A CONTAINER reflect the soul of the Romanticism person in the transformation process from earth to heaven life. In this context, artistic concept HOUSE stands for the shelter from the unknown - death: "And now before the door, / I dared not open, lest a face / I never saw before / ... / I laughed a wooden laugh / That I could fear a door, / Who danger and the dead had faced, / But never quaked before. / ... / And held my ears, and like a thief / Fled gasping from the house" [2, p. 49].

Artistic concepts of EGO CS with LIFE IS FEAR dominant (FEAR, VAIN, EMPTINESS) unveil the basic reasons of fear. The author feels desolation in uselessness of life when it is not filled with happiness: "If I can stop one heart from breaking, - / I shall not live in vain" [2, p. 10].

EGO space of LIFE IS BLISS conceptual metaphor with the central concept LOVE also includes the concepts of BLISS, FEAR, LIFE and IMMORTALITY. The bliss of life exists only in its opposition to pain, fear and suffering. Happiness of life, according to Dickinson, is love, nature, self-reflection and ability to see the best in minor things: "That I shall love always, / I offer thee / That love of life, / And life hath immortality" [2, p. 148].

The self-reflection theme-line in ego-marked contexts is represented by two dominants - SOUL IS EYES and HUMAN IS NATURE. The artistic concepts distribution of EGO CS within these dominants unveils the dichotomy of spiritual and mundane where the latter is represented by concepts DOUBT, DESPAIR and SIN. In such a context, the spiritual aspect of a human is conceptualized by soul (SOUL artistic concept) as the only just observer and judge. Eyes (EYE artistic concept) serve as the objective mediator between the worlds. Consequently, this kind of self-reflection is based on the concept of spiritual perception which is an enlightenment source: "So, safer, guess, with just my soul / Upon the window-pane / Where other creatures put their eyes, / Incautious of the sun" [2, p. 40].

The leading line of EGO CS in self-reflection theme is the battle between soul and flesh. In search of harmony, the author tries to reach the natural balance observing nature. Unique Dickinson's concept CREATIVITY uncovers author's true highest values of life - she cannot live without poetry, the most valuable crown of all god's presents: "It is little I could care for pearls / Who own the ample sea; / Or brooches, when the Emperor / With rubies pelteth me; / ... / when I see / A diadem to fit a dome / Continual crowning $m e^{\prime \prime}[2$, p. 52].

Nature (artistic concept NATURE) becomes the richest source of inspiration for many poets of Romanticism. This concept proves to be central in all thematic lines of EGO CS in Dickinson's poetry, showing that only nature brings harmony and tranquility: "The bee is not afraid of me, / I know the butterfly; / The pretty people in the woods / Receive me cordially. / The brooks laugh louder when I come, / The breezes madder play. / Wherefore, mine eyes, thy silver mists? / Wherefore, O summer's day?" [2, p. 114].

The artistic concept GOD also enters Dickinson's EGO CS within all thematic lines and becomes nucleus for the line of divine. The reconstructed dominants of this space are GOD IS HOPE and GOD IS SACRIFICE: "I hope that Father in the skies / Will lift his little girl, - / Old-fashioned, naughty, everything, - Over the stile of pearl!" [2, p. 94]. Dickinson, unlike her predecessors and contemporaries, holds an active dialogue with God: she argues, questions and hesitates: "Is Heaven a physician? / They say that He can heal; / But medicine posthumous / Is unavailable. / Is Heaven an exchequer? / They speak of what we owe; / But that negations I I'm not a party to" [2, p. 32].General EGO CS of Emily Dickinson's poetry is represented in Table 1: 
Table 1. General EGO conceptual space in Emily Dickinson's poetic texts

\begin{tabular}{|c|c|c|c|c|}
\hline DEATH & LOVE & LIFE & SELF-REFLECTION & DIVINE \\
\hline NATURE & NATURE & NATURE & NATURE & NATURE \\
\hline GOD & GOD & GOD & GOD & GOD \\
\hline SOUL & SOUL & SOUL & SOUL & SOUL \\
\hline \multirow{2}{*}{ DEATH } & DEATH & DEATH & & DEATH \\
\hline & LOVE & LOVE & LOVE & LOVE \\
\hline LIFE & LIFE & LIFE & & LIFE \\
\hline FEAR & FEAR & FEAR & & FEAR \\
\hline JOY & JOY & JOY & & JOY \\
\hline BLISS & & BLISS & BLISS & \\
\hline DESPAIR & DESPAIR & & DESPAIR & \\
\hline HEAVEN & HEAVEN & & & HEAVEN \\
\hline JOURNEY & & JOURNEY & & JOURNEY \\
\hline SEA & SEA & SEA & & \\
\hline \multirow[t]{2}{*}{ WATER } & WATER & WATER & & \\
\hline & DOUBT & & DOUBT & \\
\hline FROST & FROST & & & \\
\hline \multirow[t]{5}{*}{ IMMORTALITY } & IMMORTALITY & & & \\
\hline & HEART & & & HEART \\
\hline & LIGHT & & & LIGHT \\
\hline & PAIN & & PAIN & \\
\hline & SACRIFICE & & & SACRIFICE \\
\hline CHAOS & BIRD & BAY & CREATIVITY & DOOM \\
\hline COLD & EDEN & CHANCE & DESIRE & FAITH \\
\hline DARKNESS & FLOWER & DOOR & ENEMY & HELL \\
\hline DUST & HUMILITY & EMPTINESS & EYE & HOPE \\
\hline ENLIGHTENMENT & INSECT & EXIT & FAME & \\
\hline ETERNITY & LONELINESS & GOAL & MIND & \\
\hline GARDEN & MAN & HOUSE & POETRY & \\
\hline GREIF & OBEDIENCE & MOMENT & VISION & \\
\hline KINGDOM & SUN & OCEAN & WISDOM & \\
\hline NEW WORLD & WARMTH & POOL & & \\
\hline NIGHT & WEALTH & RIVER & & \\
\hline PRIVILEDGE & WOMAN & TIDE & & \\
\hline ROAD & & $\begin{array}{l}\text { TRANSFOR- } \\
\text { MATION }\end{array}$ & & \\
\hline SHIP & & VAIN & & \\
\hline SPIRIT & & & & \\
\hline
\end{tabular}

Conclusion. The article focuses on EGO CS space analysis of Emily Dickinson's poetry. Concept EGO, defined as metal reflection of egocentricity, forms its unique CS with dominant thematic lines of ego-marked poetic fragments. Reconstructed in terms of conceptual metaphor themedominants predetermine the distribution of artistic concepts within EGO CS.

The analysis of EGO CS of Emily Dickinson's poetic texts revealed five thematic lines: lines of death, love, life, self-reflection and divine. Common for all lines are the artistic concepts of NATURE, GOD and SOUL. The concepts DEATH, LOVE, LIFE, FEAR and JOY are identified in four thematic lines of ego-marked contexts. The rest of the concepts belong to EGO CS periphery.

EGO CS analysis of Emily Dickinson's works demonstrates author's egocentricity conceptualization that finds its metal representation in unique concept distribution within identified thematic lines. The algorithm developed may be implemented for further investigations of egocentricity in poetry and prose.

\section{REFERENCES}

1. Bingham, M. (1955). Emily Dickinson's Home. N.Y.: Harper \& Brothers Publishers.

2. Dickinson, Emily. Poems. Retrieved from URL: https://www.poemhunter.com/i/ebooks/pdf/ emily_dickinson_2012_5.pdf (11.11.2019).

3. Freeman, M. (2020). The Poem as Icon. A Study in Authentic Cognition. Oxford University Press.

4. Freud, S. (2018). The Ego and the Id. Courier Dover Publications.

5. Lakoff G., Johnson M. (1980). Metaphors We Live By. Chicago: Chicago University Press.

6. Steen, Gerard J., et al. (2011). A method for Linguistic
Metaphor Identification. Converging Evidence in Language and Communication Research. Vol. 14. Amsterdam, Philadelphia: John Benjamins Publishing Company.

7. Stockwell, P. (2002). Cognitive Poetics. An introduction. London and New York.

8. Tsur, R. (2002). Aspects of Cognitive Poetics. Cognitive Stylistics: Language and Cognition in Text Analysis / ed. by Semino E., Culpeper J. Amsterdam / Philadelphia: John Benjamins Publishing Company.

9. Ніконова, В.Г. (2007).Трагедійна картина світу в поетиці Шекспіра: монографія. Дніпропетровськ: Вид-во Дніпропетровського університету економіки та права.

\section{REFERENCES}

9. Nikonova, V.H. (2007). Trahediina kartyna svitu v poetyts Shekspira [Tragic picture of the world in Shakespeare's poet- ics]. Dnipropetrovsk: Dnipropetrovsk University of Economics and Law [in Ukrainian]. 